\title{
A linguística textual e a construção do texto: um estudo sobre os fatores de textualidade
}

\author{
Textual linguistics and the construction of text: a study on textuality factors
}

\author{
Max Silva da Rocha* \\ Universidade Estadual de Alagoas \\ Palmeira dos Índios, Alagoas, Brasil \\ Maria Margarete de Paiva Silva** \\ Universidade Estadual de Alagoas \\ Palmeira dos Índios, Alagoas, Brasil
}

Resumo: Este trabalho objetiva fazer uma reflexão sobre a Linguística Textual, buscando entender alguns conceitos e filiações dessa ciência do texto. Estuda, também, o texto e como ele é construído numa relação de leitura e escrita. Por fim, faz uma reflexão acerca da importância dos fatores de textualização como a coesão (coesão lexical, referenciação, substituição, conjunção e elisão) coerência, intertextualidade, intencionalidade, situacionalidade, informatividade e aceitabilidade.

Palavras-chave: Linguística. Critérios. Textualidade.

\begin{abstract}
This work aims to reflect on Textual Linguistics, seeking to understand some concepts and affiliations of this text science. It also studies the text and how it is constructed in a relation of reading and writing. Finally, it makes a reflection about the importance of textualization factors such as cohesion (lexical cohesion, referencing, substitution, conjunction and elision) coherence, intertextuality, intentionality, situationality, informativeness and acceptability.
\end{abstract}

Keywords: Linguistics. Criteria. Textuality.

\section{INTRODUÇÃO}

A linguística textual, doravante LT, surgiu na Europa, mais precisamente, na Alemanha, por volta da década de 1960. Nesse período das ascensões linguísticas, destacam-se nomes importantes como Halliday, Weirich, Ducrot, Dressler, Harris, Hjelmslev, Benveniste, Jakobson, Pêcheux, além de outros precursores.

As investigações desses autores deram outra visão aos estudos até então realizados pela ciência do texto. A LT transformou os métodos de trabalhar o texto. Três linhas de

* Graduado em Letras e especialista em Linguística Aplicada (UFAL). E-mail: msrletras@gmail.com.

** Mestre em Letras e Linguística (UFAL), doutoranda em Letras (UEM), professora da Universidade Federal de Alagoas. E-mail: msrletras@outlook.com. 
estudos foram predominantes nessa concepção de uma linguística voltada para o texto, a saber: a retórica, a estilística e o formalismo russo.

Se antes da LT a análise se limitava apenas ao nível da frase, passou-se, então, com esses avanços, a se estudar o texto numa perspectiva interacional. O uso da língua na interação social e num determinado contexto, ou funcionalismo linguístico, é abordado pela LT, subárea da linguística moderna (FÁVERO e KOCH, 2000, p.1).

No início de seu surgimento, essa linha de estudos não se preocupava com o texto em si, pois de acordo com Koch (2004, p.7), a LT "teve incialmente por preocupação descrever os fenômenos sintático-semânticos ocorrentes entre enunciados ou sequências de enunciados, alguns deles inclusive, semelhantes aos que já haviam sido estudados no nível da frase".

Diante do exposto, apenas as frases eram tidas como elementos de análise, porém com a expansão da LT, a partir da década de 1970, começa-se a ter interesse pela unidade básica de sentido, o texto. Nas palavras de Fávero e Koch (2000, p.11), "sua hipótese de trabalho consiste em tomar como unidade básica, ou seja, como objeto particular de investigação, não mais a palavra ou a frase, mas sim com o texto, por serem os textos a forma de manifestação da linguagem".

Mesmo com o interesse pelo todo significativo, a maior preocupação dessa corrente linguística com o seu objeto de estudo adquire destaque na década posterior, visto que "somente a partir de 1980, contudo, que ganham corpo as Teorias do Texto [...]", conforme ressalta Koch (2004, p.8). Com essa expansão, vemos as grandes investigações e as novas tendências para o estudo e ensino da materialidade textual tanto em língua materna como também estrangeira. Vê-se, pois, que o texto passa a ser o foco de estudos dessa área linguística. Sobre esse entendimento, Koch (2004, p.11) salienta:

\begin{abstract}
A Linguística Textual toma, pois como objeto particular de investigação não mais a palavra ou a frase isolada, mas o texto, considerado a unidade básica de manifestação da linguagem, visto que o homem se comunica por meio de textos e que existem diversos fenômenos linguísticos que só podem ser explicados no interior do texto. O texto é muito mais que a simples soma das frases (e palavras) que o compõem: a diferença entre frase e texto não é meramente de ordem quantitativa; é sim, de ordem qualitativa.
\end{abstract}

Sob essa perspectiva, a LT passa a dar importância aos fatores e critérios de textualidade contidos na manifestação linguística. Estudar o texto é es tudar uma estrutura dotada de sentido, com objetivações e intenções definidas, pois, de acordo com Florêncio et al. (2009, p.25-26), "não há, pois, discurso neutro ou inocente, uma vez que ao produzilo, o sujeito o faz, a partir de um lugar social, de uma perspectiva ideológica e, assim, veicula valores, crenças, visões de mundo que representa os lugares sociais que ocupa", e da mesma maneira ocorre com o texto.

O texto é, pois, a materialização máxima da língua. Na comunicação, o todo significativo pode ser verbal e não verbal. Nas palavras de Koch (2014), a LT trata o texto como um ato de comunicação unificado num complexo universo de ações humanas. Com isso, a teoria do texto está permeada por um viés interdisciplinar, visto que lança olhares para uma gama de fatores linguísticos, como o pragmático, o semântico, o lexical, o 
gramatical, ou seja, fatores que complementam a estrutura e funcionalidade do objeto de estudo dessa corrente linguística.

São vários os aspectos multiculturais que configuram um texto, pois o falante aciona uma complexa rede de fatores ao produzi-lo de forma escrita ou falada. As questões sociais, cognitivas e interacionais fazem com que os estudos da LT transformem o texto em um canal estruturado da seguinte forma: processo/ ação/ interação. Isso faz com que a LT represente um marco nas novas vertentes da linguística moderna.

É incabível abordar essa área de estudos e não mencionarmos o nome de Luiz Antônio Marcuschi, considerando que esse autor, ao lado de Ingedore Koch, deu o pontapé inicial nos estudos nessa área linguística, aqui no Brasil. Segundo o referido autor, a LT é uma das linhas mais promissoras da linguística atual, proporcionando, assim, uma ampla investigação de seu objeto de estudo.

O estudioso citado (2012, p.26) acrescenta: "neste caso, a LT é a descrição da correlação entre a produção, a constituição e a recepção de textos". Dessa maneira, essa corrente linguística "deve prestar um serviço fundamental na elaboração de exercícios e na formação da capacidade hermenêutica do leitor, ao lhe dar o instrumento que o capacita para a compreensão de textos" (MARCUSCHI, 2012, p.33).

O falante se comunica através do texto e não da frase como era abordado nos estudos linguísticos do período anterior a década de 1960. Em épocas não tão longínquas, a gramática da frase era tida como o centro dos estudos, porém esta não deu conta de analisar a materialidade textual. Para Geraldi (1996, p.64),

Aquele que aprendeu a refletir sobre a linguagem é capaz de compreender uma gramática que nada mais é do que o resultado de uma (longa) reflexão sobre a língua; aquele que nunca refletiu sobre a linguagem pode decorar uma gramática, mas jamais compreenderá seu sentido.

Diferentemente de uma concepção estritamente gramatical, na LT, notamos a preocupação com os fatores de produção, recepção e interpretação do texto. Nessa perspectiva, a LT “dispõe, porém, de um dogma de fé: o texto é uma unidade linguística hierarquicamente superior à frase. E uma certeza: a gramática de frase não dá conta do texto" (MARCUSCHI, 2012, p.16). Vê-se, pois, que a visão da LT se concentra no estudo da entidade linguística concreta e dotada de sentido.

Postas essas questões, agora destacaremos as três formas de se fazer LT: a) uma LT que tem por objeto textos numa esfera autônoma da linguagem, mesmo antes da constituição de textos nas diversas línguas. Então, texto seria aqui uma categoria universal e, nesse caso, buscaríamos regras gerais para uma competência ampla; b) uma LT que veria o texto como o nível de estruturação de cada língua. Aqui se teria algo como uma "gramática de texto" ou "gramática transfrástica", montada para cada língua como tal; c) toda a linguística nada mais é do que uma LT, já que todas as manifestações linguísticas se dão apenas com textos concretos. A gramática do texto seria o mesmo que a gramática da língua. A descrição da estrutura e funcionamento do texto seria a descrição da estrutura e funcionamento da língua (COSERIU, 1980, apud MARCUSCHI, 2012, p.32). 
Estas três posições são divergentes entre si. Coseriu (1980 apud MARCUSCHI, 2012, p.32) considera a terceira um fracasso. As outras duas são consideradas razoáveis e viáveis, mas esse autor faz uso da primeira posição (MARCUSCHI, 2012, p.32). Concomitantemente, a posição apresentada por Coseriu (1980 apud MARCUSCHI, 2012, p.32), no tocante à LT, apresenta semelhanças na ideia defendida pelo autor brasileiro.

Proponho que se veja a LT, mesmo que provisória e genericamente, como o estudo das operações linguísticas e cognitivas reguladoras da produção, construção, funcionamento e recepção de textos escritos ou orais [...]. Em suma a LT trata o texto como um ato de comunicação unificado num complexo universo de ações humanas (MARCUSCHI, 2012, p.33).

O foco da LT é o texto tanto escrito como oral, uma vez que é nesse espaço comunicativo que a linguagem se manifesta.

Centrar o ensino no texto é ocupar-se com o uso da lingua. Trata-se de pensar a relação de ensino como o lugar de práticas de linguagem e a partir delas, com a capacidade de compreendê-las, não para descrevê-las como faz o gramático, mas para aumentar as possibilidades de uso exitoso da língua (GERALDI, 1996, p.71).

Para produzir um bom texto, portanto, é importante saber utilizar os critérios de textualidade, que serão tratados mais adiante, pois necessariamente, antes de abordá-los, precisamos tratar, mais detalhadamente, da leitura e da escrita, como recursos facilitadores para a construção do texto.

\section{A IMPORTÂNCIA DA LEITURA E ESCRITA NA CONSTRUÇÃO DO TEXTO}

A invenção da escrita representa um grande marco na história da humanidade, porque antes do seu surgimento, as informações eram passadas de pai para filho de forma oral. Notadamente, na tradição oral, com o passar do tempo, as palavras se modificam, muitas informações são perdidas, há uma interferência social, política e cultural sobre a importância das informações, fazendo com que algumas não sejam repassadas.

A escrita proporciona a permanência da informação. Ela perdura no tempo. Desse modo, a memória coletiva dos povos passou a ter outros meios de materialização: os hieróglifos, os papiros. Na modernidade, jornais, revistas, livros e internet. Vale dizer que a escrita se constitui como um divisor de águas na história da humanidade. "As palavras determinam nosso pensamento porque não pensamos com pensamentos, mas com palavras, não pensamos a partir de uma genialidade ou inteligência, mas a partir de nossas palavras" (LARROSA, 2002, p.21).

A atividade da escrita, na maioria das escolas, ainda é priorizada em detrimento da leitura, que é considerada como atividade fundamental a ser desenvolvida na escola. Convém destacar que a escrita tem como finalidade precípua a leitura e não o contrário. É a escola a instituição responsável pela sistematização do saber, por isso precisa ter a 
leitura como atividade básica que pode dar ao aluno o devido suporte para uma produção de texto bem elaborada.

Nessa perspectiva, é pertinente destacar o dizer de Cagliari (2009, p.148-149): “A leitura é a extensão da escola na vida das pessoas. A maioria do que se deve aprender na vida terá de ser conseguido através da leitura fora da escola". Ocorre que a maioria das escolas tem a escrita como prioridade e, ainda assim, escreve-se pouco e, muitas das vezes, com incidentes. Devemos considerar que a escrita, como atividade interativa, implica relação cooperativa entre duas ou mais pessoas. Sendo assim, toda atividade interativa deve pressupor um possível interlocutor, para que haja esmero. Quem escreve deve naturalmente escrever para alguém ou com alguma finalidade e não simplesmente como atividade para correção.

Para Rocha e Ferro (2016), o ato de escrever implica ter o que dizer. Quem escreve, escreve pensando no outro, que, por sua vez, se constitui enquanto leitor. A capacidade de saber, de poder, de liberdade é essencial à realização do interlocutor enquanto pessoa e, consequentemente, como ser social, que precisa do outro para interagir. É a leitura que serve como base para o êxito na escrita. Já a escrita, no entendimento de Antunes (2005, p.45), é

A atividade da escrita é então uma atividade interativa de expressão, (ex: 'para fora'), de manifestação verbal das ideias, informações, intenções, crenças ou dos sentimentos que queremos partilhar com alguém, para, de algum modo interagir com ele. Ter o que dizer é, portanto, uma condição prévia para o êxito da atividade de escrever.

$\mathrm{Na}$ produção de um texto, as frases e as palavras não funcionam isoladamente, uma a uma, mas estabelecem uma conexão de sentido. O texto é um jogo de perguntas e respostas entre os termos. Aliado a isso, o uso da escrita serve justamente para estabelecer esse processo de comunicar de forma coerente e coesa. Quem escreve escreve para ser lido, e a palavra escrita serve como um elo/laço entre quem fala e quem ouve; entre quem escreve e quem lê.

O texto serve como ponte entre os interlocutores do processo de comunicação, por isso, ao escrevermos, é imprescindível levarmos em conta esse interlocutor, como sujeito do processo da interação verbal, para que ele possa entender o que foi escrito. No que se refere à escrita enquanto o processo de interação, é válido destacar o que afirma Bakhtin (1995, p.113):

Na realidade toda palavra comporta duas faces. Ela é determinada tanto pelo fato de que procede de alguém como pelo fato de que se dirige para alguém. [...] A palavra é uma espécie de ponte lançada entre mim e os outros. Se ela se apóia (sic) sobre mim numa extremidade, na outra se apóia (sic) sobre o meu interlocutor.

$\mathrm{Na}$ escrita textual, é necessário considerar as normas que regem a produção de um bom texto e, sobretudo, entender o que é um texto. Do ponto de vista de Koch (2014, p.30), 
[...] para que uma manifestação linguística constitua um texto, é necessário que haja a intenção do produtor de apresentá-la - e a dos parceiros de aceitá-la como tal -, em uma situação de comunicação determinada. Pode, inclusive, acontecer que, em certas circunstâncias, se afrouxe ou elimine deliberadamente a coesão e/ ou coerência semântica do texto com o objetivo de produzir efeitos específicos. Aliás, nunca é demais lembrar que a coerência não constitui uma propriedade ou qualidade do texto em si: um texto é coerente para alguém, em dada situação de comunicação específica. [...]. Este alguém, para construir a coerência, deverá levar em conta não só os elementos linguísticos que compõem o texto, mas também seu conhecimento enciclopédico, conhecimentos e imagens mútuas, crenças, convicções, atitudes, pressuposições, intenções explícitas ou veladas, situação comunicativa imediata, contexto sociocultural e assim por diante.

Vale salientar a necessidade de garantir o sentido nas produções textuais, levando em conta que o sentido do texto não se encontra nele, o sentido é construído a partir do próprio texto, conforme Koch (2014). Pode-se afirmar que o texto é uma (re)construção do mundo e não uma simples refração ou reflexo. Analisamos a constituição do texto, adentramos profundamente na estrutura textual, verificando como acontece essa construção e quais os critérios textuais regem a produção de texto.

\section{O TEXTO COMO UM EVENTO COMUNICATIVO}

A produção textual é uma interação entre sujeitos com objetivos sociocomunicativos, sendo a comunicação o principal. Produzir um texto é lidar com várias situações relevantes, tais como: expectativa, crenças, as mais diversas visões de mundo, pré-conhecimentos, pressuposições, convicções, entre outras. E, ao considerar todas essas situações, o produtor usa o texto como instrumento mediador para atingir a sua principal meta, a de comunicar. O texto precisa ser visto como uma unidade de "[...] sentido, necessitando para isso de uma situação discursiva, de interlocutores, das categorias de espaço e tempo e de um propósito claro e definido; e de elementos da linguagem, analisados em sua visão global, especificada pela análise vocabular e referencial" (SANTOS, 2013, p.56).

Uma gama de regras, no entanto, precisa ser observada e seguida, o que torna complexo o objeto de estudo da LT. Um texto é uma unidade mínima significativa de sentido, independentemente de sua extensão, conforme ressaltam Halliday e Hasan (1976, p.195). Falar de texto é falar de comunicação e produção de sentidos que edificam o ambiente da interação entre um produtor e um receptor, por isso um texto não pode ser escrito de qualquer forma, haja vista que o sistema da língua não permite tal situação, como frisa Rocha (2015).

Nesse entendimento, afirmam Azevedo e Tardelli (2004, p.45): "produzir um texto na escola é, pois, realizar uma atividade de elaboração que se apura nas situações interlocutivas criadas em sala de aula; é um trabalho de reflexão individual e coletiva e não um ato mecânico, espontaneísta ou meramente reprodutivo". Um texto é uma produção de sentido e requer o máximo de cuidado ao ser produzido. Mas, não foi sempre assim, pois ocorreram transformações linguísticas, concepções de linguagem etc. Segundo Antunes (2009, p.50-51), 
As definições e classificações categóricas, que são possíveis no âmbito da palavra e da frase isoladas, foram dando lugar às dependências enunciativas e contextuais. Nessa perspectiva, as palavras e as frases passaram a ganhar pleno sentido somente na medida em que são vistas como partes de textos, como componentes de discursos, pelos quais as pessoas dizem, agem, participam, tomam posições, se firmam no aqui e no agora de sua existência.

Nos dias atuais, temos o texto como evento comunicativo situado num espaço sociointerativo. Há ainda que se considerar a concepção de texto. Essa concepção é totalmente diferente ao ser comparada em dois níveis no ensino básico e no nível superior, são duas situações distintas, mas passíveis de análises.

No ensino básico, percebemos claramente as inconsistências encontradas nas produções textuais dos alunos, resultantes da forte influência da fala na escrita dos discentes. Além disso, a perpetuação do ensino que usa o texto como pretexto para o ensino gramatical e a correção meramente estrutural e ortográfica contribuem para que vários textos continuem apresentando sérios problemas linguísticos, visto que não é exigida, por parte do corpo docente, uma reescrita e retextualização das produções, conforme Matêncio (2002). A reescrita ajuda o aluno a compreender que o texto segue um padrão de regras lineares.

No ensino superior, diferentemente do ensino básico, a concepção de texto é outra, uma vez que os acadêmicos de Letras mantêm contanto direto com os parâmetros linguísticos e isso proporciona uma gama de recursos eficientes para uma boa construção textual, embora, também encontremos problemas atípicos em produções acadêmicas, não solucionados na educação básica.

A situação ideal seria que o ensino-aprendizagem, na educação básica, proporcionasse aos alunos a escrita de um texto com começo, meio e fim, adequando a escrita à norma culta da língua, amarrando as ideias numa sequência lógica de sentidos. Ocorre que a realidade não condiz com o esperado: no ensino superior, em vez de se trabalhar a escrita científica, obedecendo às regras acadêmicas, a fim de expor contribuições para a ciência e para a sociedade, os professores, na maioria das vezes, estão tentando, primeiramente, sanar as deficiências dos alunos, para que eles, no final da graduação, na produção do Trabalho de Conclusão de Curso/ TCC, possam demonstrar resultados satisfatórios do aprendizado.

Vários teóricos reforçam a ideia de analisar as categorias textuais. Dentre eles, destacamos Marcuschi (2008, p.72), para quem o texto "É a unidade de manifestação da linguagem", ou seja, o texto é o ambiente no qual a comunicação se materializa. Ele não é um amontoado de palavras, portanto precisa se adequar ao sistema, pois a sequenciação é primordial, entendendo que as partes de um todo semântico devem estar interligadas por vários critérios de textualidade. Nesse sentido, é imprescindível destacar o ponto de vista de Koch (2014, p.30):

Um texto se constitui enquanto tal no momento em que os parceiros de uma atividade comunicativa global, diante de uma manifestação linguística, pela atuação conjunta de uma complexa rede de fatores de ordem situacional, cognitiva, sociocultural e interacional, são capazes de construir para ele, determinado sentido. 
O texto, oral ou escrito, possibilita estudos e análises que têm a língua como recurso, tomando como base a comunicação verbal. No dizer de Marcuschi (2008, p.51), há pelo menos dezenove pontos que podem ser trabalhados através de produções textuais, a saber: a) as questões do desenvolvimento histórico da língua; b) a língua em seu funcionamento autêntico; c) as relações entre as diversas variantes linguísticas; d) as relações entre fala e escrita no uso real da língua; e) a organização fonológica da língua; f) os problemas morfológicos em seus vários níveis; g) o funcionamento e a definição de categorias gramaticais; h) os padrões e a organização de estruturas sintáticas; i) a organização do léxico e a exploração do vocabulário; j) o funcionamento dos processos semânticos da língua; k) a organização das intenções e os processos pragmáticos; l) as estratégias de redação e questões de estilo; m) a progressão temática e a organização tópica; n) a questão da leitura e da compreensão; o) o treinamento do raciocínio e da argumentação; p) o estudo dos gêneros textuais; q) o treinamento da ampliação, redução e resumo de texto; r) o estudo da pontuação e da ortografia; e s) os problemas residuais da alfabetização.

Esses fenômenos, ora mencionados, podem ser trabalhados de forma interativatextual em sala de aula, haja vista que muitos textos do ensino básico são problemáticos e complexos, trazendo sobre eles os mais diversos fenômenos linguísticos, ou seja, essas produções textuais formam um campo rico para pesquisas, uma vez que os textos

Por vezes, eles carecem de coesão, formando conjuntos de frases soltas e, em outras, a têm em excesso causando enorme volume de repetições tópicas [...]. De resto, os textos escolares revelam ignorância e descompasso em relação à complexidade da produção oral dos alunos (MARCUSCHI, 2008. p.53).

De um ponto de vista crítico, a pesquisa é essencial para transformar essa triste realidade. É tentando viabilizar uma melhoria nestas produções textuais, ricas em incidentes, que a LT propõe novos olhares e perspectivas de mudança. Ensinar a produzir, compreender e analisar textualmente é o principal foco dos estudos linguísticos nessa área, numa perspectiva sociointeracionista. "No quadro de uma concepção sociointeracionista da linguagem, o fenômeno social da interação verbal é o espaço próprio da realidade da língua, pois é nele que se dão as enunciações enquanto trabalho dos sujeitos envolvidos nos processos de comunicação social" (GERALDI, 1996, p.27).

Essa linha de análise evidencia que o aluno tem que aprender a ser um produtor de seus próprios discursos, mas também ter uma visão crítica no discurso do outro. "Nessa perspectiva, o trabalho em língua materna parte do enunciado e suas condições de produção para entender e bem produzir textos" (MARCUSCHI 2008, p.55). A visão socionteracionista adotada em sala de aula possibilita uma grande transformação social, fazendo do aluno um participante ativo na produção do sentido.

Inspirado em Bakhtin, entende-se que o sujeito se constitui como tal à medida que interage com os outros, sua consciência e seu conhecimento do mundo resultam como 'produto inacabado' deste mesmo processo no qual o sujeito internaliza a linguagem não é o trabalho 
de um artesão, mas trabalho social e histórico seu e dos outros e para os outros e com os outros que ela se constitui. Isto implica que não há um sujeito dado, pronto, que entra em interação, mas um sujeito se completando e se construindo nas suas falas e nas falas dos outros (GERALDI, 1996, p.19).

A construção dos conhecimentos, de um ethos, de uma identidade vai se estruturando a partir da interação com o outro, nesse caso, por meio dos textos. Há que se considerar, também, que textos orais e escritos possuem formas, estilos e composições, manifestados em diferentes gêneros textuais/ discursivos e que o sentido permeia cada produção. O sentido, na perspectiva deste estudo, refere-se ao todo coerente, o texto. Dessa maneira, analisar as formas da unidade básica de sentido é essencial para conhecer, por exemplo, como um aluno faz uso de elementos linguísticos com o intuito de efetuar a comunicação desejada e a interação com o outro.

Para Bentes (2006), o texto não pode ser analisado em partes isoladas e sim em seu todo significativo, uma vez que o falante consegue produzir textos, reformulá-los, qualificá-los, graças a competência textual inata ao usuário de língua materna. O objetivo da LT, nessa perspectiva, é estudar como se forma o texto, a função e a produção dele nas mais variadas modalidades.

Nessa abordagem de estudo, a comunicação pode ser oral ou escrita. No entanto, o ensino básico, na maioria das vezes, não dá o devido valor a fala. Ela não é tão estudada, sistematicamente, como a escrita. Isso é problemático, pois, como Marcuschi (2008, p.53) alerta, “[...] ao se enfatizar o ensino da escrita não se deve ignorar a fala, pois a escrita reproduz a seu modo e com regras próprias, o processo interacional da conversação, da narrativa oral e do monólogo, para citar alguns". A escola, por exemplo, deve ter por finalidade a leitura como centro do saber e, concomitantemente, a escrita e a fala.

A escrita e a fala são bases lineares da comunicação, da produção de texto, e não são poucos os textos que apresentam reflexos da oralidade na escrita, porque "um texto não se esclarece em seu pleno funcionamento apenas no âmbito da língua, mas exige aspectos sociais e cognitivos", os quais também incluem a oralidade (MARCUSCHI, 2008, p.65).

É nesse âmbito, ou seja, de não analisar somente os pontos linguísticos dos textos, que a concepção interacional se faz presente. A produção textual na sala de aula deve levar em conta alguns fatores que são imprescindíveis, como: a leitura, que deve sempre estar em primeiro lugar; e a escrita e a fala, que precisam ter os mesmos valores no ensinoaprendizagem, porque ambas direcionam o caminhar das ideias.

Ao se trabalhar com textos de alunos no espaço escolar, deve-se lembrar que o discente já vem com uma grande bagagem de conhecimento e ele já tem um modo concreto de se expressar. Cabe ao professor aproveitar da melhor maneira possível esse conhecimento prévio e acrescentar as novas tendências linguísticas. Para Marcuschi (2008, p.76),

[...] o trabalho com a língua portuguesa, na perspectiva de uma LT, teria de se ocupar com algo a mais do que o ensino e aprendizagem de regras ou normas de boa formação de 
sequências linguísticas. Trata-se de um estudo em que se privilegia a variada produção e suas contextualizações na vida diária.

É necessário analisar todos os aspectos possíveis que regem a produção textual, pois "o texto é um evento comunicativo em que convergem ações linguísticas, sociais e cognitivas" (BEAUGRANDE, 1997 apud MARCUSCHI, 2008, p.72) e precisa ser explorado ao máximo.

O texto possui um todo semântico mediado por critérios de textualidade que funcionam como base constituinte desse complexo significativo, são elas: coesão, coerência, informatividade, situacionalidade intertextualidade, intencionalidade e aceitabilidade, conforme nos mostra Marcuschi (2008).

Continuando a discussão, iremos compreender os critérios textuais que servem de base central para o estudo e para a estruturação do tex to "[...] sendo a coesão e a coerência (relacionados aos conhecimentos linguísticos) e os outros critérios, como a aceitabilidade, a informatividade, a situacionalidade, a intertextualidade e a intencionalidade, relacionados ao conhecimento de mundo e à contextualização" (SANTOS, 2013, p.85).

\section{FATORES DE TEXTUALIZAÇÃO}

A partir de agora, passamos a estudar os fatores de textualização. Esses, por sua vez, dão uma ancoragem ao texto em uma situação comunicativa determinada. Sem eles, não poderia haver qualquer coerência na produção linguística (KOCH e TRAVAGLIA, 2015 , p.81). Esses critérios ajudam a estabelecer o texto e, dessa maneira, garantir-lhe a coerência. Os fatores de textualização funcionam como contextualizadores do evento comunicativo. Eles agem juntos, a fim de manter o entendimento e situar o leitor no espaço em que se dá a comunicação. Diante disso, "os fatores de contextualização desempenham um papel muito importante no estabelecimento da coerência” (KOCH e TRAVAGLIA, 2015, p.84).

\subsection{COESÃO}

No que diz respeito à coesão, convém frisar que é a ligação coerente entre as partes de um texto, produzida por uma escolha correta de operadores textuais; ela funciona como um conector entre frases e parágrafos e tem como função agir, juntamente com a coerência, para dar um sentido amplo ao texto. Sobre essa interdependência, Koch (2014, p.58) ressalta:

Portanto, nos textos em que a coesão está presente - já que ela não é condição nem necessária, nem suficiente da coerência -, pode-se afirmar que ambas passam a constituir as duas faces de uma mesma moeda, ou então, para usar de uma outra metáfora, o verso e o reverso desse complexo fenômeno que é o texto.

Considerando que a coesão funciona como parte do sistema de uma língua, embora se trate de uma relação semântica, ela é realizada, como ocorre com todos os componentes 
do sistema semântico, através do léxico gramatical. No entendimento de Santos (2013, p.93), “[...] o uso adequado de elementos coesivos atribui ao texto maior legibilidade, mostrando os tipos de relações estabelecidas entre os elementos linguísticos que o compõem", criando, dessa forma, um laço/elo coesivo. "A rigor, pode-se dizer que o segredo da coesão textual está precisamente na habilidade demonstrada em fazer essa 'costura' ou tessitura das sequências tipológicas como uma armação de base, ou seja, uma malha infraestrutural do texto" (MARCUSCHI, 2005, p.27). A coesão possibilita a progressão sistemática do texto.

$\mathrm{Na}$ coesão, temos subáreas que são imprescindíveis na produção de um texto. São elas: a coesão lexical, a referenciação, a substituição, a conjunção e a elisão. São mecanismos linguístico-gramaticais que proporcionam uma produção textual coerente e coesa e evitam vãs repetições.

\subsection{COESÃO LEXICAL}

É obtida pela repetição de itens lexicais idênticos ou que possuam o mesmo referente, como bem lembra Fávero (2003). Com isso, nota-se a importância de tais mecanismos na construção de bons textos, facilitando a elaboração de produções e o entendimento do leitor. Sobre a perspectiva de coesão lexical, Antunes (2005, p.50) afirma: "É impossível, pois, ressaltar que a continuidade que se instaura pela coesão é, fundamentalmente, uma continuidade de sentido, uma continuidade semântica, que se expressa, no geral, pelas relações de reiteração, associação e conexão".

Salientamos que também é válido o que destaca Koch $(2004$, p.18) sobre a coesão lexical: "[...] pode-se afirmar que o conceito de coesão textual diz respeito a todos os processos de sequencialização que asseguram (ou tornam recuperável) uma ligação linguística significativa entre os elementos que ocorrem na superfície textual". De acordo com Fávero (2003), a coesão textual pode ser referencial anafórica ou catafórica, responsáveis por formar compartimentos coesivos mais ou menos longos.

\subsection{REFERENCIAÇÃO}

"A coesão referencial é a que se estabelece entre dois ou mais componentes da superfície textual que remetem a (ou permite recuperar) um mesmo referente (que pode evidentemente, ser acrescido de outros traços que se lhe vão agregando textualmente)" (KOCH e TRAVAGLIA, 2015, p.47-48). A coesão referencial é utilizada nos textos para fazer menção a termos anteriormente mencionados, não perdendo, assim, a linearidade do texto. É retomada de sentidos dentro do próprio texto por meio de referentes. Ainda seguindo a definição, Koch $(2004$, p.31) salienta: "Chamo, pois, de coesão referencial aquela em que um componente da superfície do texto faz remissão a outro(s) elemento(s) nela presentes ou inferíveis a partir do universo textual". A coesão referencial pode ser anafórica ou catafórica.

A anafórica faz referência a um signo já expresso e a referencial catafórica a um signo ainda não expresso. Existem, portanto, três tipos: a) pessoal (pronomes pessoais e 
possessivos); b) demonstrativa (pronomes demonstrativos e advérbios de lugar); e c) comparativa (por via indireta, através de similares). Diante disso, "a expressão referencial é uma estrutura linguística utilizada para manifestar formalmente, na superfície do texto (ou seja, no cotexto), a representação de um referente" (CAVALCANTE; CUSTÓDIO FILHO e BRITO, 2014, p.28).

\subsection{SUBSTITUIÇÃO}

A substituição consiste na colocação de um item no lugar de outro(s): nominal, por meio de pronomes pessoais, numerais, etc; verbal, pelo qual o verbo "fazer" substitui o causativo "ser", substituto existencial; elipse, por omissão de um item identificável pelo contexto e através das conjunções, que não são por si só coesivas, mas, indiretamente, por estabelecer relações entre as orações. E, também, a reiteração que incide na repetição de expressões. Logo, a substituição

Consiste, para Halliday e Hasan, na colocação de um item em lugar de outro(s) elemento(s) do texto, ou até mesmo, de uma oração inteira. Seria uma relação interna ao texto, em que uma espécie de 'coringa' é usado em lugar da repetição de um item particular (KOCH, 2004, p.20).

O mecanismo da substituição é utilizado como objeto facilitador para que o texto não cometa ambiguidades ou redundâncias desnecessárias, como também serve para tornar a produção textual linear e coesa.

\subsection{CONJUNÇÃO}

A Conjunção está ligada à sequencialização textual, como a causalidade, a temporalidade, a consequência, dentre outras orações subordinadas e/ou coordenadas, e ela serve para tornar o texto linear e sequencial. Sobre a conjunção, assim diz Fávero (2003, p.14):

[...] tem natureza diferente das outras relações coesivas por não se tratar simplesmente de uma relação anafórica. Os elementos conjuntivos são coesivos não por si mesmos, mas indiretamente, em virtude das relações específicas que se estabelecem entre as orações, períodos e parágrafos. Essas diferentes relações conjuntivas possuem uma série de equivalentes estruturais.

Vemos claramente que as conjunções propulsionam a linearidade e o sentido das orações subordinadas e coordenadas. São expressões como: mas, todavia, contudo, nem, e, embora, pois, porque, etc. Ainda sobre esse mecanismo coesivo, é de suma importância salientar o que pontua Koch (2004, p.21):

A conjunção ou (conexão) permite estabelecer relações significativas específicas entre elementos ou orações do texto. Tais relações são assinaladas explicitamente por marcadores formais que correlacionam o que está para ser dito. Trata-se dos diversos tipos de conectores 
e partículas de ligação como e, mas, depois, assim, etc. Halliday e Hasan apresentam, como principais tipos de conjunção, a aditiva, a adversativa, a causal, a temporal e a continuativa.

Depreendemos que a conjunção é um mecanismo imprescindível para as normas da produção textual, uma vez que ela viabiliza uma construção concatenada e dotada de sentido por meio dos conectores.

\subsection{ELISÃO}

O último elemento atrelado à coesão, neste estudo, é a elisão. Esse mecanismo coesivo ocupa, no texto, a função de omissão e representa uma ideia de sujeito oculto no enunciado. Nas palavras de Fávero (2003, p.14), a elisão é a "omissão de um item lexical recuperável pelo contexto, ou seja, a substituição por zero (0). Pode ocorrer elipse de elementos nominais, verbais e oracionais". Complementando essa ideia, Koch (2004, p.21) ressalta que "A elipse seria, então, uma substituição por zero: omite-se um item lexical, um sintagma, uma oração ou todo um enunciado, facilmente recuperáveis pelo contexto". Vemos, dessa maneira, que a elipse aparece como um recurso coesivo, a fim de tornar o texto uma unidade básica de sentido.

\subsection{COERÊNCIA}

Quanto à coerência, é pertinente salientar que diz respeito à estrutura profunda do texto. "Diz-se que um texto é coerente quando há unidade de sentido entre as partes que o constituem. A base da coerência está centrada na continuidade de sentidos entre os conhecimentos ativados pelas expressões do texto" (SANTOS, 2013, p.93-94).

Este critério relaciona-se ao sentido do texto e é imprescindível na produção textual, pois ela está atrelada à ordem das ideias e dos argumentos. É totalmente ligada à coesão. Sem coerência, o texto torna-se impossível de ser entendido e não comunica. "Portanto, para haver coerência é preciso que haja a possibilidade de estabelecer no texto alguma forma de unidade ou relação entre seus elementos" (KOCH, 2014, p.22).

A coerência em um texto se apresenta em forma de sentido e de enunciados ligados de maneira ordenada, significativa e de fácil entendimento por parte do leitor para chegar à compreensão do texto como um todo coerente. Essa ordenação consiste em expor as ideias de forma concatenada, de modo que remetam a um item já expresso e, ao mesmo tempo, em renovar conteúdos, ou serão apenas meras repetições que tornam o texto incoerente, sem nenhuma informação que contraponha o que foi mencionado anteriormente. Para Antunes (2009, p.93), a coerência diz respeito a

Construir um texto, capaz de funcionar sociocomunicativamente num contexto específico, uma operação de natureza também lexical e gramatical. Quer dizer, não se pode escolher aleatoriamente as palavras nem arrumá-las de qualquer jeito; nem tampouco optar por qualquer sequência de frases. 
É necessário um conhecimento linguístico por parte do escritor e do leitor para não tornar os textos um emaranhado de palavras sem significação alguma, de difícil decodificação. Palavras ou frases soltas não podem ser consideradas textos. Para a produção ou leitura de um texto coerente, são indispensáveis três tipos de conhecimento, a saber: o conhecimento enciclopédico (memória semântica), que é a organização dos conhecimentos e situações do mundo real nas quais são estabelecidas relações lógicas; o conhecimento linguístico, que compreende o conhecimento tanto lexical, quanto gramatical que dão total suporte linguístico à estrutura superficial do texto, isto é, à linearidade sequencial e referencial da produção textual (KOCH, 2014, p.32). Por último, temos o conhecimento sociointeracional, que consiste na organização de interação e de ações verbais da linguagem, seguindo modelos globais como nos esclarecem Fávero (2003) e Koch (2014).

Em outras palavras, para a produção de um texto coerente e coeso, é fundamental não só dominar as regras que norteiam a língua, mas também ter uma vivência, conhecimento de mundo por parte do produtor, que buscará informações sobre o repertório do público-alvo. Caso isso não ocorra, o texto possivelmente será incoerente diante do tipo de situação e de receptor ao qual ele se destina.

\subsection{INTERTEXTUALIDADE}

Esse fator permite uma ligação na qual os textos se comunicam com outros textos. A intertextualidade nos mostra a interdependência de um texto para com o outro, porque um texto só tem sentido em relação e comparado a um outro. "A intertextualidade implícita acontece porque a produção trata de um tema que dialoga com outros textos, havendo uma comunidade explícita em relação ao tema proposto" (SANTOS, 2013, p.90).

Não existem textos que não mantenham algum aspecto intertextual, pois nenhum texto encontra-se isolado. Todos os textos têm uma relação com outros textos já ditos, dos quais absorve algumas características para atribuir outra feição.

Isso significa que todo texto é um objeto heterogêneo, que revela uma relação radical de seu interior com seu exterior; e, desse exterior, evidentemente, fazem parte outros textos que lhe dão origem, que o predeterminam, com os quais dialoga, que retoma, a que alude, ou, a que opõe (KOCH, 2014, p.59).

No entendimento de Marcuschi (2008, p.130), "pode-se dizer que a intertextualidade é uma propriedade constitutiva de qualquer texto e o conjunto das relações explícitas ou implícitas que um texto ou um grupo de textos determinados mantém com outros textos". Assim, vemos uma ligação direta ou indireta de um texto com outro todo significativo, o que compreende a intertextualidade. É pertinente destacar que "a intertextualidade colabora com a coerência textual uma vez que ajuda a entender o sentido veiculado no texto". Os critérios de textualização se unem para formar a cadeia/progressão textual (SANTOS, 2013, p.98). 


\title{
4.9 INTENCIONALIDADE
}

Este critério nos passa uma ideia sobre o que o texto e o autor pretendem tratar durante todo o desenrolar do enunciado. É válido citar o que pontuam Koch e Travaglia (2015, p.97):

\begin{abstract}
Como vimos, o produtor de um texto tem, necessariamente, determinados objetivos ou propósitos, que vão desde a simples intenção de estabelecer ou manter o contato com o receptor até a de levá-lo a partilhar de suas opiniões ou a agir ou comportar-se de determinada maneira. Assim, a intencionalidade refere-se ao modo como os emissores usam textos para perseguir e realizar suas intenções, produzindo, para tanto, textos adequados à obtenção dos efeitos desejados.
\end{abstract}

O critério da intencionalidade está muito associado à argumentatividade, conforme Koch e Travaglia (2015). Para os autores, não existem textos neutros, pois há sempre uma intenção por trás do dito. Nesse sentido, há uma argumentatividade, a fim de persuadir, convencer e criar um mundo com as próprias crenças, convicções etc.

Já com base em Marcuschi (2008), a intencionalidade está ligada aos objetivos pretendidos pelo autor. Ela revela o esforço do produtor do texto em construir uma comunicação eficiente, capaz de proporcionar um discurso tanto coerente quanto coeso e, assim, satisfazer os objetivos de ambos os interlocutores. "Acrescente-se a isso a ideia de a intencionalidade trabalhar com a aceitabilidade, pois se entendida a primeira, a segunda surge como consequência" (SANTOS, 2013, p.98).

Considera-se a intenção do autor como um fator relevante para a textualização, pois nenhum texto é inocente, pois têm uma intenção. Um texto é produzido com uma finalidade que deve ser compreendida pelo leitor. "Com base na intencionalidade, costuma-se dizer que um ato de fala, um enunciado, um texto é produzido com objetivo, uma finalidade que deve ser captada pelo leitor" (MARCUSCHI, 2008, p.127). Dessa forma, o texto deverá ser compatível com os objetivos de quem o elabora.

\subsection{SITUACIONALIDADE}

A situacionalidade é justamente a adequação da manifestação linguística a uma situação comunicativa do texto e está relacionada ao contexto, sempre se referindo ao fato de relacionar o evento textual à situação comunicativa. A situação ajuda a direcionar o sentido do discurso, tanto em sua produção como também em seu entendimento. Essa situação comunicativa interfere diretamente na produção do texto. Sob esse olhar, é válido destacar o que acrescentam Koch e Travaglia (2015, p.85):

É preciso, ao construir um texto, verificar o que é adequado àquela situação específica: grau de formalidade, variedade dialetal, tratamento a ser dado ao tema, etc. O lugar e o momento da comunicação, bem como as imagens recíprocas que os interlocutores fazem uns dos outros, os papéis que desempenham, seus pontos de vista, o objetivo da comunicação, enfim, todos os dados situacionais vão influir tanto na produção do texto, como na sua compreensão. 
Vê-se, desse modo, que a função desse critério de textualidade é adequar o texto à situação em que há uma comunicação. O modo como os produtores de um texto situam um contexto no qual a produção se embasa cria uma cadeia linear coerente. Segundo Marcuschi (2008, p.128), "a situacionalidade não só serve para interpretar e relacionar o texto ao seu contexto interpretativo, mas também para orientar a própria produção. A situacionalidade é um critério estratégico".

Ela parte do texto para a situação e da situação para o texto. Na primeira, o produtor cria, a partir do texto, um mundo que não é uma cópia do mundo real, mas crenças, convicções, que o produtor tem do mundo criado por ele mesmo a partir do texto. A segunda concepção, por sua vez, parte do contexto de produção para a situação comunicativa, isto é, do contexto sociocultural no momento de determinada produção. "Assim, na construção da coerência, a situacionalidade exerce também um papel de relevância. Um texto que é coerente em dada situação pode não sê-lo em outra: daí a importância da adequação do texto à situação comunicativa" (KOCH e TRAVAGLIA, 2015, p.86).

\subsection{INFORMATIVIDADE}

Todo texto é produzido com a intenção de ser lido e compreendido pelo receptor da comunicação. Desse modo, o rema ${ }^{1}$ a ser trabalhado dever tratar, essencialmente, de contextos acessíveis ao leitor. No mais, o critério da informatividade faz com que o texto se torne coerente no desenvolvimento dos tópicos referentes ao conteúdo. Temos, no entanto, que tomar bastante cuidado, pois o conhecimento sobre os temas a serem abordados precisam ser aprofundados.

Também devemos observar que o excesso de informações pode desmotivar o leitor por não poder armazená-las na totalidade. É importante que o texto trate de informações que tragam novidades, mas que sejam compreensíveis. "A rigor, a informatividade diz respeito ao grau de expectativa ou falta de expectativa, de conhecimento ou desconhecimento e mesmo incerteza do texto oferecido" (MARCUSCHI, 2008, p.132). A informação é, essencialmente, necessária nesse contexto, pois ela é responsável por mostrar o que o texto quer transmitir. De acordo com Koch e Travaglia (2015, p.88),

É a informatividade, portanto, que vai determinar a seleção e o arranjo das alternativas de distribuição da informação no texto, de modo que o receptor possa calcular-lhe o sentido com maior ou menor facilidade, dependendo da intenção do produtor de construir um texto mais ou menos hermético, mais ou menos polissêmico, o que está, evidentemente, na dependência da situação comunicativa e do tipo de texto a ser produzido.

Portanto, a informatividade interfere na construção da coerência do texto e é parte importante na sua interpretação, ela é a informação trazida pelo produtor do tópico discursivo e nos diz do que trata determinada produção.

\footnotetext{
${ }^{1}$ Na visão de Koch (2014), o rema é a informação nova, a partir de um tema dado.
} 


\subsection{ACEITABILIDADE}

A aceitabilidade está totalmente ligada à intencionalidade e diz respeito à atitude do receptor do texto. De acordo com Marcuschi (2008, p.128), “A aceitabilidade, enquanto critério de textualidade, parece ligar-se às noções pragmáticas e ter uma estreita interação com a intencionalidade [...]". Como a aceitabilidade diz respeito à expectativa do receptor, Como a aceitabilidade diz respeito à expectativa do receptor, há dificuldade em estabelecer os seus limites. Com isso,

A aceitabilidade constitui a contraparte da intencionalidade. Já disse que, segundo o Princípio Cooperativo de Grice, o postulado básico que rege a comunicação humana é o da cooperação, isto é, quando duas pessoas interagem por meio da linguagem, elas se esforçam por fazer-se compreender e procuram calcular o sentido do texto do(s) interlocutor(es), partindo das pistas que ele contém e ativando seu conhecimento de mundo, da situação, etc. (KOCH e TRAVAGLIA, 2015, p.98).

A aceitabilidade é inerente ao receptor, porque ela analisa o nível de coerência e coesão que o texto utiliza, sendo capaz de levar o receptor a aceitar o texto produzido e, consequentemente, ampliar os seus conhecimentos, visto que "um texto é construído com uma finalidade que deve ser percebida pelo leitor” (SANTOS, 2013, p.98), no qual advém a aceitação ou não da produção linguística.

\section{CONSIDERAÇÕES FINAIS}

As reflexões da Teoria Textual realizadas neste breve estudo puderam evidenciar que um texto é dotado de fatores de textualização, os quais precisam ser observados para que o todo significativo progrida e comunique de uma forma coerente e coesa. Notou-se, também, que os aspectos textuais sustentam uma produção de texto, dando forma e, sobretudo, função a um determinado texto produzido.

Percebeu-se que os fatores de textualidade fazem com que o texto se torne um conjunto de orações concatenadas por uma estrutura concreta. Verificou-se que os sete critérios de textualidade apresentados por Marcuschi (2008) fazem com que qualquer texto passe uma mensagem significativa, dotada de sentido, criandouma ponte entre o leitor e o produtor da manifestação linguística.

Logo, ficou evidente que os critérios de textualidade precisam ser conhecidos e trabalhados nas mais diversas comunidades discursivas, para fazer com que produtores de texto possam se familiarizar com esses mecanismos textuais e, dessa forma, consigam produzir textos coerentes e coesos, visto que o ensino-aprendizagem, principalmente da escrita, poderia ter resultados satisfatórios se os fatores de textualidade fossem estudados e didatizados para serem utilizados numa produção de texto. 


\section{REFERÊNCIAS}

ANTUNES, Irandé. Lingua, texto e ensino: outra escola possível. São Paulo: Parábola Editorial, 2009.

Lutar com palavras: coesão e coerência. São Paulo: Parábola Editorial,

2005.

AZEVEDO, Claudinéia B. e TARDELLI, Marlete C. Escrevendo e falando na sala de aula. In: CHIAPPINI, Lígia. Aprender e ensinar com textos de alunos. São Paulo: Parábola Editorial, 2004.

BAKHTIN, Mikhail. Marxismo e Filosofia da Linguagem. 7. ed. São Paulo: Hucitec, 1995.

BENTES, Anna Christina. Linguística Textual. In: MUSSALIM, Fernanda;

Introdução à linguística: domínios e fronteiras. 2. ed. São Paulo: Cortez, 2006.

CAGLIARI, Luís Carlos. Alfabetização e Linguística. 11. ed. São Paulo: Scipione, 2009.

CAVALCANTE, Mônica Magalhães; CUSTÓDIO FILHO, Valdinar; BRITO, Mariza Angélica Paiva. Coerência, referenciação e ensino. São Paulo: Cortez, 2014.

FÁVERO, Leonor Lopes. Coesão e coerência textuais. São Paulo: Ática, 2003.

Paulo: Cortez, 2000.

; KOCH, Ingedore G. Villaça. Linguística textual: introdução. 5. ed. São

FLORÊNCIO, Ana Maria Gama et al. Análise do Discurso: Fundamentos e Prática. Maceió: Edufal, 2009.

GERALDI, João Wanderley. Linguagem e ensino: exercícios de militância e ensino. Campinas, SP: Mercado de Letras, 1996.

HALLIDAY, M. A. K.; HASAN, Ruqaiya. Cohesion in English. New York: Longman, 1976.

KOCH, Ingedore. A coesão textual. 19. ed. São Paulo: Contexto, 2004.

. O texto e a construção dos sentidos.10. ed. São Paulo: Contexto, 2014.

; TRAVAgliA, Luiz Carlos. A coerência textual. 18. ed. São Paulo:

Contexto, 2015. 
LARROSA, Jorge. Notas sobre a experiência e o saber da experiência. Trad. João Wanderley Geraldi. In: Revista Brasileira de Educação, 2002.

MARCUSCHI, Luiz Antônio. Gêneros textuais: definição e funcionalidade. In: DIONÍSIO, Angela Paiva; MACHADO, Anna Rachel; BEZERRA, Maria Auxiliadora. Gêneros textuais e ensino. 4. ed. Rio de Janeiro: Lucerna, 2005.

. Linguística textual: o que é e como se faz. São Paulo: Parábola Editorial, 2012.

Editorial, 2008. Produção textual, análise de gêneros e compreensão. 3. ed. São Paulo: Parábola

MATENCIO, M. L. M. Atividades de retextualização em práticas acadêmicas: um estudo do gênero resumo. Scripta, Belo Horizonte, v. 6, n. 11, p. 25-32, 2002.

ROCHA, Max Silva da. Texto na escola: um olhar sob o viés da linguística textual. In: Encontro das ciências da linguagem aplicadas ao ensino (ECLAE), 6., 2015, Garanhuns. Anais eletrônicos do VI ECLAE. Garanhuns, PE: Pipa comunicação, 2015, p. 3451-3461.

ROCHA, Max Silva da; FERRO, Maria Betânia Alves. Os processos de leitura e de escrita na formação do profissional docente. Querubim, Niterói/RJ, v.4, n.30, p.11-17, janeiro de 2016.

SANTOS. Maria Francisca Oliveira. Os saberes construidos no processo da pesquisa. Maceió, AL: Edufal, 2013. 